\title{
Bacterial cell membrane adaptation responses on stress caused with the environmental pollutants
}

\author{
Slavomíra Murínová, Katarína Dercová \\ Slovak University of Technology, Faculty of Chemical and Food Technology, \\ Institute of Biotechnology and Food Science, Department of Biochemical Technology, \\ Radlinského 9, 81237 Bratislava, Slovakia \\ slavomira.murinova@gmail.com
}

\begin{abstract}
The effect of polychlorinated biphenyls on biomass production, lipid accumulation, and on the fatty acid profile of the major membrane lipids of Alcaligenes xylosoxidans isolated from a soil long-term contaminated with polychlorinated biphenyls was examined. The lowest bacterial growth was observed in the presence of biphenyl and polychlorinated biphenyls. On the other hand, the highest growth stimulation was observed in the presence polychlorinated biphenyls. Higher growth ability was observed when polychlorinated biphenyls or 3-chlorobenzoic acid were added after three days of cultivation. Higher lipid accumulation corresponded with lower growth ability. The importance of time when bacterial strain meets polychlorinated biphenyls or 3-chlorobenzoic acid should be emphasized. The addition of toxic organic compound later in stationary growth phase led to better survival and evoked lower membrane adaptation. However, polychlorinated biphenyls or 3-chlorobenzoic acid amendment at the beginning of cultivation stimulated adaptation responses as membrane saturation, cis to trans isomerisation, and branched fatty acids alteration and decreased growth ability. Palmitic acid and 17-cyclopropyl fatty acid were observed as prevalent in the bacterial membrane as well as in the total lipids.
\end{abstract}

Key words: adaptation mechanisms, bacteria, environmental stress, fatty acids, polychlorinated biphenyls

\section{Introduction}

Polychlorinated biphenyls (PCBs) represent an environmental concern due to their toxicity, persistence and environmental recalcitrance. These chemicals were used principally in transformer oils and as electric insulants (Kočan et al., 1994). The major threats come from their accumulation in the food chain and their toxicity that is structurally related. They can act as endocrine disruptors of human and wild life populations. Due to these facts, they are considered as hazardous waste (Vrana et al., 1996; Kočan et al., 2001; Dercová et al., 2008). Many techniques have been invented to destroy these hazardous pollutants (Gorbunova et al., 2010). Physical and chemical remediation technologies of PCBs in natural environment are costly to introduce. Bioremediation technologies using degradation capacity of bacteria has long been seen as a cost-effective way to eliminate diffusive contamination caused with PCBs in various environmental matrices, e.g. soils, sediments, and sludges (Tandlich et al. 2011). Successful soil bioaugmentation requires not only application of a strain or a consortium with the particular degradative ability, but also of the microorganisms able to survive in the adverse environment (Dercová et al. 2009; Mrozik et al. 2010; Megharaj et al. 2011; Ohtsubo et al. 2000). Poor survival of the inoculated microorganisms and low bioavailability of the pollutant are usually the main obstacles to the successful inoculum amendment.

Although, many bacteria have the ability to metabolize PCBs, high concentrations of these chemicals in the environment inhibit cells survival and their ability to metabolize PCBs. If bacterial strains wanted to survive, they had to develop efficient adaptation mechanisms in the hostile environment (Čertík and Breierová 2002; Zorádová et al. 2011). Such resistant bacteria may play a major role in bioremediation technologies.

Being at the interface between the cell and the environment, the cytoplasmic membrane is the first site of contact between the cell and contaminant. Hydrophobic pollutants change the saturation of bacterial membrane that can lead into a significant disturbance of physiological function and cell death. This is the reason why membrane flexibility and adaptation ability largely determines the survival of the cell (Čertík et al., 2003; Denich et al., 2003). Since fatty acids are the major constituents of membrane phospholipids, modulation of number and position of double bonds of acyl chains by specific fatty acid desaturases plays crucial role in preserving a suitable dynamic state of the bilayer during environmental impact (Šajbidor, 1997). Polychlorinated biphenyls affect the saturation of membrane fatty acids of various bacterial strains by increasing the saturation of fatty acids 
(Zorádová et al., 2011). A correlation between an increase in the degree of saturation of membrane fatty acids and increased tolerance towards the toxic compounds in phenol-degrading strain $P$. putida $\mathrm{P} 8$ was desribed (Heipieper et al., 1992). This phenomenon is thought to be the major long-time adaptive mechanism in microorganisms exposed to toxic aromatic compounds. Other membrane adaptation mechanism cis/trans izomerization of unsaturated fatty acids (UFAs) can be observed under growth-inhibiting conditions. Steric differences between cis and trans configurations reduce membrane fluidity (Heipieper et al 2003). Changes in branched fatty acids can be observed in adverse environment as well. Transition temperatures of the branched fatty acids are lower for the anteiso fatty acids. This difference together with steric differences causes a remarkable change in the fluidity of the membrane when the species of branched fatty acids are changed from one form to another. The effect on transition temperature caused by a change from anteiso- to iso-branching is comparable to the isomerization of cis- to trans unsaturated fatty acids (Unell et al. 2007).

The purpose of this study was to analyze the effect of PCBs as potential stress factors on the cell membrane, especially on the profile of fatty acids in the membrane lipids of a strain Alcaligenes xylosoxidans previously monitored for PCB degradation (Dercová et al., 1996).

Biphenyl is a known inducer of the bacterial PCB metabolic pathway (Furukawa et al., 1978; Donnelly et al., 1994) and several terpenes e.g. carvone and limonene (Gilbert and Crowley, 1997; Hernandez et al., 1997) have been shown to promote PCB degradation by $\mathrm{PCB}$-degrading bacteria. We therefore examined the effect of the addition of biphenyl or carvone simultaneously with PCBs at lag or stationary growth phase on the fatty acids profile. Finally, we also examined the effect of growing the cells in the presence of 3-chlorobenzoic acid (3-CBA) a dead-end PCB metabolite known to significantly inhibit the bacterial growth and the degradation ability of PCB degraders. Moreover, chlorobenzoic acids are considered to be more toxic than PCBs (Vrana et al., 1997; Martinéz et al., 2007) and are usually accumulated in the environment because PCB-degrading strains are not able to degrade them.

\section{Materials and methods}

\section{Microorganism}

The bacterial strain Alcaligenes xylosoxidans was isolated from long-term PCB-contaminated soil as described previously by Dercová et al. (1996). The strain was identified and maintained at the Czech Collection of Microorganisms (CCM), Masaryk University, Brno, Czech Republic. The strain was negatively evaluated as containing $b p h A$ gene encoding biphenyl dioxygenase (the first enzyme of PCB degradation pathway) in nucleus DNA however did not question the possibility of presence of plasmid bphA gene (Tandlich et al. 2001)

\section{Chemicals}

A commercial formulation of PCBs, DELOR 103, containing 40-42 \% (w/v) of bound chlorine (Chemko Strážske, Slovakia), n-hexane, methanol, chloroform, glucose and dimethylsulfoxide (DMSO) (Mikrochem, Slovakia), culture broth No. 2 (Imuna, Slovakia), and chemicals for minimal mineral medium (Lachema Brno, Czech Republic) were used.

A commercial formulation of PCBs, DELOR 103, containing 40-42\% (w/v) of bound chlorine (Chemko Strážske, Slovakia), n-hexane, methanol, chloroform, glucose and dimethylsulfoxide (DMSO) (Mikrochem, Slovakia), culture broth No. 2 (Imuna, Slovakia), chemicals for minimal mineral medium (DMA) (Lachema Brno, Czech Republic), 3-CBA (Merck, Germany), biphenyl (Merck, Germany), carvone (Merck, Germany) were used. Because of the low solubility of PCBs, 3-CBA, biphenyl, and carvone in water, all of them were added to the DMA medium (Dercová et al., 1996) as solutions in DMSO. The concentration of DMSO did not exceed $2 \%$ in the whole volume of DMA medium in flask.

\section{Cultivation conditions}

All flasks contained $5 \mathrm{~g} . \mathrm{l}^{-1}$ glucose as carbon source and $0.5 \mathrm{~g} . \mathrm{l}^{-1}$ of 48 hour old inocula of $A$. xylosoxidans. The inoculum was prepared in $200 \mathrm{ml}$ of culture broth No. 2 in $500 \mathrm{ml}$ flasks. The incubation of the flasks took 6 days in darkness at $28^{\circ} \mathrm{C}$ with shaking (150 rpm). A control set containing only glucose as sole organic chemical was run in parallel. PCBs were added at the final concentration of $100 \mathrm{mg} \cdot \mathrm{l}^{-1}$ in two sets: in lag phase (at the time of inoculation) or in stationary growth phase (after three days of cultivation without PCBs). The experiments were performed using following additions or their combinations: (1) addition of PCBs; (2) PCBs and carvone; (3) PCBs and biphenyl; (4) 3-CBA alone. The purpose of the experiment was to determine the difference between cells exposed to PCBs early in the growth phase and cells exposed to PCBs later, in the stationary phase. Carvone and biphenyl were added to the DMA medium at the beginning of the cultivation at the final concentration of $10 \mathrm{mg} \cdot .^{-1}$. 3-CBA was added at the same concentration as PCBs also in 
two sets: at the beginning of cultivation and after three days of cultivation.

\section{Lipid isolation and fractionation}

The whole flasks after cultivation were centrifuged $(1500 \times \mathrm{g}$ for $5 \mathrm{~min})$ to harvest the bacterial biomass. The sediment was dried at $65^{\circ} \mathrm{C}$ for 10 hours and weighted. Lipids from the homogenized dry biomass were isolated with chloroform:methanol (2:1, v/v) (Čertík \& Šajbidor, 1996). The lipids were subsequently fractionated by thin-layer chromatography (TLC). To separate polar lipids, $5 \%$ lipid solution in $\mathrm{n}$-hexane was applied to the TLC plates (Silica gel $60,20 \times 20 \mathrm{~cm}, 0.5 \mathrm{~mm}$ layer, Merck, Germany) and developed with the solvent system chloroform:aceto ne:methanol:acetic acid:water (50:20:10:10:5, v/v) (Čertík \& Shimizu, 2000). The stripes were visualized with iodine vapor and identified by comparison of their $\mathrm{R}_{\mathrm{f}}$ values with the known standards. The major membrane lipids (phosphatidylethanolamine) and non-polar lipids were scraped off (iodine vapor and water traces were removed under reduced pressure) and then extracted from the silica twice with chloroform:methanol (1:1, v/v). Organic phases were pooled (silica gel was removed by centrifugation), solvent was evaporated under reduced pressure and lipid structures were subsequently analyzed.

\section{Fatty acid analysis}

Fatty acids of total lipids, non-polar lipids, and phosphatidylethanolamine were analyzed by gas chromatography (GC) as their methyl esters according to Christopherson and Glass (1969) using an Agilent model 6890 GC (Agilent Technologies) equipped with a $60 \mathrm{~m} \times 0.25 \mathrm{~mm}$ capillary column DB-23 (film thickness $0.25 \mu \mathrm{m}$, Agilent Technologies) and a FID detector. The chromatographic conditions were as follows: constant flow, hydrogen $40 \mathrm{ml} \cdot \mathrm{min}^{-1}$, air
$450 \mathrm{ml} \cdot \mathrm{min}^{-1}, 250{ }^{\circ} \mathrm{C}$; the temperature was held at $150{ }^{\circ} \mathrm{C}$ for $3 \mathrm{~min}$ then raised to $175^{\circ} \mathrm{C}$ at a rate of $7^{\circ} \mathrm{C} \cdot \mathrm{min}^{-1}$, held at $175^{\circ} \mathrm{C}$ for $5 \mathrm{~min}$ then raised at $195^{\circ} \mathrm{C}$ at a rate of $5^{\circ} \mathrm{C} \cdot \mathrm{min}^{-1}$ and at $225^{\circ} \mathrm{C}$ at a rate of $4.5^{\circ} \mathrm{C} \cdot \mathrm{min}^{-1}$; it was held at $225^{\circ} \mathrm{C}$ for $0.5 \mathrm{~min}$ and lowered at $215^{\circ} \mathrm{C}$ at a rate of $10^{\circ} \mathrm{C} \cdot \mathrm{min}^{-1}$ and finally held at $240{ }^{\circ} \mathrm{C}$ for $7 \mathrm{~min}$. Hydrogen was the carrier gas at a flow $2.5 \mathrm{ml} . \mathrm{min}^{-1}$, velocity of $57 \mathrm{~cm} . \mathrm{s}^{-1}$ and pressure of $220 \mathrm{kPa}$. The sample was injected at a split ratio of $1 / 20$ (Injector $230{ }^{\circ} \mathrm{C}$; hydrogen flow $51 \mathrm{ml} . \mathrm{min}^{-1}$ for $2 \mathrm{~min}$, then $20 \mathrm{ml} . \mathrm{min}^{-1}$; pressure $220 \mathrm{kPa}$ ). The fatty acid methylester peaks were identified by authentic standards of $\mathrm{C}_{4}-\mathrm{C}_{24}$ fatty acid methylesters mixture (Supelco, USA) and evaluated by ChemStation B 0103 (Agilent Technologies) (Maruna et al., 2010).

\section{Results and discussion}

Membrane fatty acids are known as a part of adaptation system where the type and amount of acyl chains of phospholipids alter the membrane fluidity required to respond to environmental perturbances (Heipieper et al. 1994; Duldhardt et al. 2010). The purpose of the experiments was to determine the differences in adaptation mechanisms in the cells exposed to PCBs early in the growth phase (lag phase) and cells exposed to PCBs in the stationary phase. Cell adaptation ability was evaluated with the lipid accumulation, bacterial growth, and the differences in fatty acid profile in the bacterial lipid fractions including cis/trans ratio of unsaturated fatty acids, degree of saturation, and changes in branched fatty acids.

\section{Effect of PCBs and 3-CBA on the bacterial growth and lipid accumulation}

The vast concentrations of toxic organic compounds inhibit bacterial growth and promote cells

Tab. 1. Biomass concentration and lipid accumulation after six days of cultivation. Control experiment was not enriched with PCBs, PCB0 - PCBs were added at the time of inoculation, PCB3 - PCBs were added to three-day cultivation, bip - biphenyl was added at the time of inoculation, car - carvone was added at the time of inoculation, CBA0 - 3-CBA was added at the time of inoculation, CBA3 - 3-CBA was added to three-day cultivation.

\begin{tabular}{ccc}
\hline Experimental set & Biomass concentration $\left(\mathbf{g} \cdot \mathbf{1}^{-1}\right)$ & Lipid accumulation $(\%)$ \\
\hline control & $1.71 \pm 0.12$ & $10,31 \pm 0.31$ \\
PCB0 & $2.09 \pm 0.07$ & $9.53 \pm 0.93$ \\
PCB3 & $2.12 \pm 0.17$ & $6.65 \pm 0.21$ \\
bip + PCB0 & $1.58 \pm 0.16$ & $13.62 \pm 0.12$ \\
bip + PCB3 & $1.86 \pm 0.12$ & $8.36 \pm 0.29$ \\
car + PCB0 & $1.63 \pm 0.02$ & $12.22 \pm 1.16$ \\
car + PCB3 & $2.07 \pm 0.05$ & $11.93 \pm 1.43$ \\
CBA0 & $1.13 \pm 0.13$ & $14.95 \pm 0.26$ \\
CBA3 & $2.03 \pm 0.02$ & $5.54 \pm 0.05$ \\
\hline
\end{tabular}


death (Dercová et al., 2004). The growth inhibition or deceleration of growth rate is one of the first indicators of cell membrane damage in bacteria. Another consequence of adverse environment is lipid accumulation. It is expressed as the lipid mass percentage in dry biomass. The higher stress is present in the environment, the more massive lipid accumulation can be observed (Čertík et al. 2003). Tab. 1 shows bacterial growth after six-day cultivation.

According to our observations, addition of PCBs alone in both experimental sets increased biomass amount compared to control experiment. This increase was similar for both sets. The results of lipid accumulation corresponded with bacterial growth. This accumulation was lower compared to control experiment whereby smaller accumulation was observed when PCBs were added in stationary growth phase. The addition of biphenyl and PCBs at lag phase decreased biomass compared to control and significantly increased the lipid accumulation. PCBs added to the medium with biphenyl after three day cultivation had opposite effect. The addition of carvone with PCBs had similar influence to biomass growth. However, the lipid accumulation was stimulated with carvone in both experimental types compared to control or addition of PCBs alone. Extreme differences were noticed after 3-CBA addition. The addition of the acid in lag phase of bacterial growth led into a significant biomass inhibition and highest lipid accumulation whereas its addition in stationary growth phase increased the amount of $A$. xylosoxi dans and rapidly decreased lipid accumulation. This parameter achieved half value of control accumulation.

These results are in agreement with those reported by Zorádová et al. (2011) and Zorádová-Murínová et al. (2012) where significant reduction of growth of different bacterial strains was observed when persistent organic pollutants were added at the time of inoculation. Opposite effect was observed by Dercová et al. (2004). When biphenyl and PCBs (and to lesser extent when carvone and PCBs) were added simultaneously at the time of inoculation, the biomass growth was lower than in culture receiving PCBs alone. Therefore we suppose that the biomass growth, based on cell weight, was inhibited by biphenyl and carvone when added simultaneously with PCBs. On the other hand, the addition of biphenyl or carvone at the beginning of cultivation (lag phase) and PCBs after three days (stationary growth phase) stimulated bacterial growth compare to control. This increase was lower than that observed just for PCBs. According to the results, we assume that biphenyl and carvone could be use as co-substrates because of the higher growth compared to control, however they should be added in stationary growth phase rather that at the beginning of cultivation. Other observations indicate that PCBs create better environment for the growth of A. xylosoxidans than the combination of PCBs with other organic compounds.

\section{Effect of PCBs and 3-CBA on lipid composition}

We examined the effect of addition of PCBs in presence or absence of biphenyl and carvone or the effect of 3-CBA on the bacterial fatty acid composition of the total lipids and the major membrane lipid, phosphatidylethanolamine. Based on GC-MS analysis, two fatty acids, palmitic acid (16:0) and 9, 10-methylenehexadecanoic acid (17-cyclopropyl fatty acid, 17-CP), comprised together more than $80 \%$ of total fatty acids in the control (medium without PCBs). Similar amount was observed when we analyzed the main membrane fraction - phosphatidylethanolamine. Their amount in all lipid types was dependent on the cultivation conditions (Tab. 2).

Our results clearly indicate that the lipid profile differs significantly depending on whether PCBs were added at the time of inoculation or in stationary phase. When PCBs were added in stationary phase, the amounts of both dominant fatty acids (16:0 and 17-CP) were significantly decreased in the main membrane fraction phosphatidylethanolamine and total lipids compared to the control without PCBs (Tab. 2). In this case, the reduction of the amount of 16:0 and 17-CP was accompanied by the stimulation of the accumulation of branched fatty acids in bacterial membrane. On the other hand, when PCBs were added in lag phase, no significant difference was observed in the content of these fatty acids in membrane lipids.

Carvone added simultaneously with PCBs did not cause significant changes in the prevalent fatty acids (Tab. 3). However, when PCBs were added in the stationary growth phase to the medium with carvone addition, the amounts of both fatty acids 16:0 and 17-CP were slightly reduced compared to the control. The presence of PCBs as well as 3-CBA in the medium enhanced the accumulation of oleic (16:1-9c) and cis-vaccenic (18:1-11c) acids in membrane. This accumulation was stimulated in the presence of biphenyl and carvone as well. Biphenyl together with PCBs in both experimental sets (addition of PCBs at the beginning and after three days) inhibited the synthesis of the 16:0 fatty acid in total lipids and 17-CP in both lipid types.

In the presence of 3-CBA or PCBs, palmitic and 9, 10-methylenehexadecanoic acids were the prevalent acids. 
Tab. 2. Fatty acid composition of phosphatidylethanolamine (PE) and total lipids (TL) of A. xylosoxidans after six days of cultivation. Control experiment was performed without PCBs or 3-CBA, PCB0 - PCBs were added at the time of inoculation, PCB3 - PCBs were added to three-day cultivation, CBA0 - 3-CBA was added at the time of inoculation, CBA3 - 3-CBA was added to three-day cultivation.

\begin{tabular}{|c|c|c|c|c|c|c|c|c|c|c|c|}
\hline \multirow{2}{*}{\multicolumn{2}{|c|}{$\begin{array}{l}\text { Sample } \\
\text { Lipid type }\end{array}$}} & \multicolumn{2}{|c|}{ Control } & \multicolumn{2}{|c|}{ РCB0 } & \multicolumn{2}{|c|}{ PCB3 } & \multicolumn{2}{|c|}{ CBA0 } & \multicolumn{2}{|c|}{ CBA 3} \\
\hline & & TL & $\mathbf{P E}$ & TL & PE & TL & PE & TL & $\mathbf{P E}$ & TL & $\mathbf{P E}$ \\
\hline \multirow{19}{*}{$\begin{array}{l}\text { Fatty } \\
\text { acids } \\
\%\end{array}$} & $14: 0$ & 1.38 & 1.14 & 1.02 & 1.53 & 1.10 & 1.50 & 2.12 & 1.94 & 1.69 & 1.53 \\
\hline & $14: 0-2 \mathrm{met}$ & 0.54 & 0.62 & 0.56 & 0.93 & 0.30 & 1.51 & 2.46 & 1.91 & 0.60 & 0.67 \\
\hline & $14: 0-3 \mathrm{met}$ & 0.52 & 0.62 & 0.27 & 0.42 & 0.26 & 1.35 & 2.51 & 1.99 & 0.67 & 0.78 \\
\hline & $15: 0$ & 0.31 & 0.19 & 0.16 & 0.16 & 0.17 & 1.49 & 0.50 & 0.34 & 0.28 & 0.18 \\
\hline & $15: 0-2 \mathrm{met}$ & 0.22 & 0.41 & 0.12 & 0.18 & 0.16 & 1.31 & 1.45 & 1.57 & 0.39 & 0.62 \\
\hline & $16: 0$ & 51.87 & 36.41 & 28.01 & 37.88 & 27.78 & 31.91 & 44.60 & 42.41 & 52.71 & 39.41 \\
\hline & $16: 1-9 \mathrm{t}$ & 0.26 & 0.23 & 0.05 & 0.17 & 0.10 & 1.25 & 0.30 & 0.24 & 0.29 & 2.06 \\
\hline & $16: 1-9 c$ & 0.32 & 0.28 & 0.09 & 0.27 & 0.10 & 1.36 & 0.34 & 0.66 & 0.19 & 0.53 \\
\hline & $16: 0-2 \mathrm{met}$ & 0.22 & 0.05 & 0.46 & 0.19 & 0.53 & 1.57 & 0.54 & 0.38 & 0.14 & 0.14 \\
\hline & $16: 0-3 \mathrm{met}$ & 0.17 & 0.14 & 0.05 & 0.13 & 0.11 & 1.48 & 0.88 & 0.28 & 0.23 & 0.36 \\
\hline & $17: 0$ & 0.22 & 0.19 & 0.11 & 0.17 & 0.12 & 0 & 0.43 & 0.29 & 0.20 & 0.19 \\
\hline & 17-CP & 36.69 & 53.24 & 23.55 & 51.74 & 23.06 & 36.98 & 30.22 & 33.90 & 35.72 & 47.55 \\
\hline & $18: 0$ & 1.63 & 1.80 & 0.93 & 1.82 & 0.65 & 1.69 & 1.91 & 2.07 & 1.67 & 1.97 \\
\hline & $18: 1-9 \mathrm{t}$ & 0.24 & 0.04 & 0.27 & 0.02 & 0.19 & 0 & 0.25 & 0.03 & 0.28 & 0 \\
\hline & $18: 1-11 t$ & 1.73 & 0.03 & 8.57 & 0.04 & 8.83 & 1.58 & 1.67 & 0.15 & 3.82 & 0.88 \\
\hline & $18: 1-9 \mathrm{c}$ & 0.15 & 0.22 & 0.22 & 0.07 & 0.20 & 1.23 & 0.40 & 0.10 & 0.08 & 0 \\
\hline & $18: 1-11 c$ & 2.94 & 0.14 & 15.03 & 0.30 & 15.72 & 1.46 & 2.05 & 1.48 & 4.06 & 3.36 \\
\hline & 19-CP & 3.81 & 4.19 & 2.27 & 3.95 & 1.97 & 10.88 & 5.75 & 5.61 & 3.38 & 3.91 \\
\hline & 20:0 & 0.43 & 0.07 & 0.54 & 0.04 & 0.58 & 1.46 & 0.77 & 0.37 & 0.36 & 0.16 \\
\hline
\end{tabular}

Tab. 3. Fatty acid composition of phosphatidylethanolamine (PE) and total lipids (TL) of A. xylosoxidans after six days of cultivation. Experimental conditions according to tab. 1.

\begin{tabular}{|c|c|c|c|c|c|c|c|c|c|}
\hline \multirow{2}{*}{\multicolumn{2}{|c|}{$\begin{array}{l}\text { Sample } \\
\text { Lipid type }\end{array}$}} & \multicolumn{2}{|c|}{ car + PCB0 } & \multicolumn{2}{|c|}{ car + PCB3 } & \multicolumn{2}{|c|}{ bip + PCB0 } & \multicolumn{2}{|c|}{ bip + PCB3 } \\
\hline & & TL & PE & TL & $\mathbf{P E}$ & TL & $\mathbf{P E}$ & TL & $\mathbf{P E}$ \\
\hline \multirow{19}{*}{$\begin{array}{l}\text { Fatty } \\
\text { acids } \\
\%\end{array}$} & $14: 0$ & 1.24 & 1.79 & 1.69 & 1.60 & 0.91 & 1.87 & 0.87 & 1.47 \\
\hline & 14:0-2met & 0.61 & 1.06 & 0.42 & 0.92 & 0.78 & 1.25 & 0.82 & 2.45 \\
\hline & $14: 0-3 \mathrm{met}$ & 0.30 & 0.50 & 0.34 & 0.30 & 0.29 & 0.61 & 0.41 & 1.39 \\
\hline & $15: 0$ & 0.19 & 0.22 & 0.20 & 0.28 & 0.18 & 0.45 & 0.16 & 0.25 \\
\hline & $15: 0-2 \mathrm{met}$ & 0.15 & 0.25 & 0.18 & 0.81 & 0.16 & 0.78 & 0.25 & 0.93 \\
\hline & $16: 0$ & 30.94 & 40.35 & 34.18 & 35.81 & 28.60 & 39.95 & 21.92 & 37.98 \\
\hline & $16: 1-9 \mathrm{t}$ & 0.08 & 0.28 & 0.13 & 0.31 & 0.20 & 0.41 & 0.15 & 0.29 \\
\hline & $16: 1-9 c$ & 0.10 & 0.60 & 0.13 & 0.30 & 0.06 & 0.82 & 0.29 & 0.46 \\
\hline & $16: 0-2 \mathrm{met}$ & 0.43 & 0.09 & 0.22 & 0.39 & 0.43 & 0.50 & 0.30 & 0.26 \\
\hline & 16:0-3met & 0.04 & 0.11 & 0.09 & 0.50 & 0.06 & 1.87 & 0.11 & 0.15 \\
\hline & $17: 0$ & 0.14 & 0.20 & 0.13 & 0.24 & 0.13 & 0.41 & 0.12 & 0.23 \\
\hline & 17-CP & 21.94 & 47.22 & 22.26 & 49.25 & 19.14 & 41.66 & 17.98 & 43.99 \\
\hline & 18:0 & 0.99 & 1.89 & 1.04 & 2.28 & 0.91 & 1.90 & 0.83 & 2.70 \\
\hline & $18: 1-9 t$ & 0.13 & 0.02 & 0.09 & 0.37 & 0.26 & 0 & 0.22 & 0.06 \\
\hline & $18: 1-11 t$ & 8.20 & 0.11 & 8.22 & 1.05 & 9.55 & 0.68 & 12.11 & 0.37 \\
\hline & $18: 1-9 c$ & 0.21 & 0.03 & 0.21 & 0.65 & 0.14 & 0 & 0.20 & 0.09 \\
\hline & $18: 1-11 \mathrm{c}$ & 13.98 & 1.21 & 11.61 & 0.44 & 17.68 & 2.89 & 22.33 & 1.52 \\
\hline & 19-CP & 1.95 & 3.96 & 1.87 & 3.94 & 2.13 & 4.57 & 2.35 & 4.89 \\
\hline & 20:0 & 0.53 & 0.13 & 0.56 & 0.58 & 0.62 & 0.80 & 0.63 & 0.53 \\
\hline
\end{tabular}


Effect of PCBs and 3-CBA on membrane adaptation

Previous works described an increase in saturation of membrane phospholipids in the presence of toxic organic compounds as phenol, PAHs, and organic solvents (Heipieper et al. 1994; Čertík et al. 2003; Dercová et al. 2004; Bernal et al. 2007; Mrozik et al. 2010). However, information about the effect of PCBs is rarely accessible.

Fig 1 shows the lipid saturation of bacterial membrane (phosphatidylethanolamine) and total lipids. Similar results can be found in both lipid fractions. The addition of PCBs in lag phase increased membrane saturation compared to control. This increase was observed in the presence of biphenyl and carvone as well. Similarity was monitored for the experiment with 3-CBA. On the other hand, the addition of PCBs or 3-CBA at the stationary growth phase decreased membrane lipid saturation. Increase of lipid saturation of total lipids were observed only for the addition of 3-CBA in lag phase of the bacterial growth. In other experimental sets was this parameter lower than at control. The addition of PCBs in lag phase led into higher total lipid saturation compared to when we added PCBs in the stationary phase. Similarity was observed when we added biphenyl or carvone.

The mechanism of increase membrane lipid saturation has limitations due to the conditions of synthesis of the saturated fatty acids. In bacteria, only the energy-dependent de novo biosynthesis of saturated fatty acids allows the increase in the degree of saturation. This is the major reason why alteration in degree of saturation was observed only in growing cells (Heipieper et al. 1994). Due to this fact, we decided to measure cis to trans unsaturated fatty acids (UFAs) isomerisation as another adaptation mechanism. This mechanism is catalyzed by enzyme isomerase and is independent on bacterial growth (Heipieper et al., 2003).

According to the results obtained from the measurements of trans/cis ratio (Fig 2) it could be concluded that the presence of PCBs or 3-CBA from the beginning of cultivation decreased the trans/ cis ratio of membrane unsaturated fatty acids compared to control. This was caused by the enormous increase of the production of cis isomers of UFAs (Tab. 2). The higher amount of trans isomers was observed when PCBs or 3-CBA were added after three days from inoculation. An increase of $\mathrm{cis}$ isomers could be observed under the same conditions as well, however in a smaller extent. The trans/cis ratio of total lipids increased when 3-CBA were added into cultivation media. This increase was caused by a decrease of cis isomers and slight increase of trans isomers when 3-CBA was added at the time of inoculation and rapid increase of trans isomers (doubled amount compared to the control) when 3-CBA were added in the stationary growth

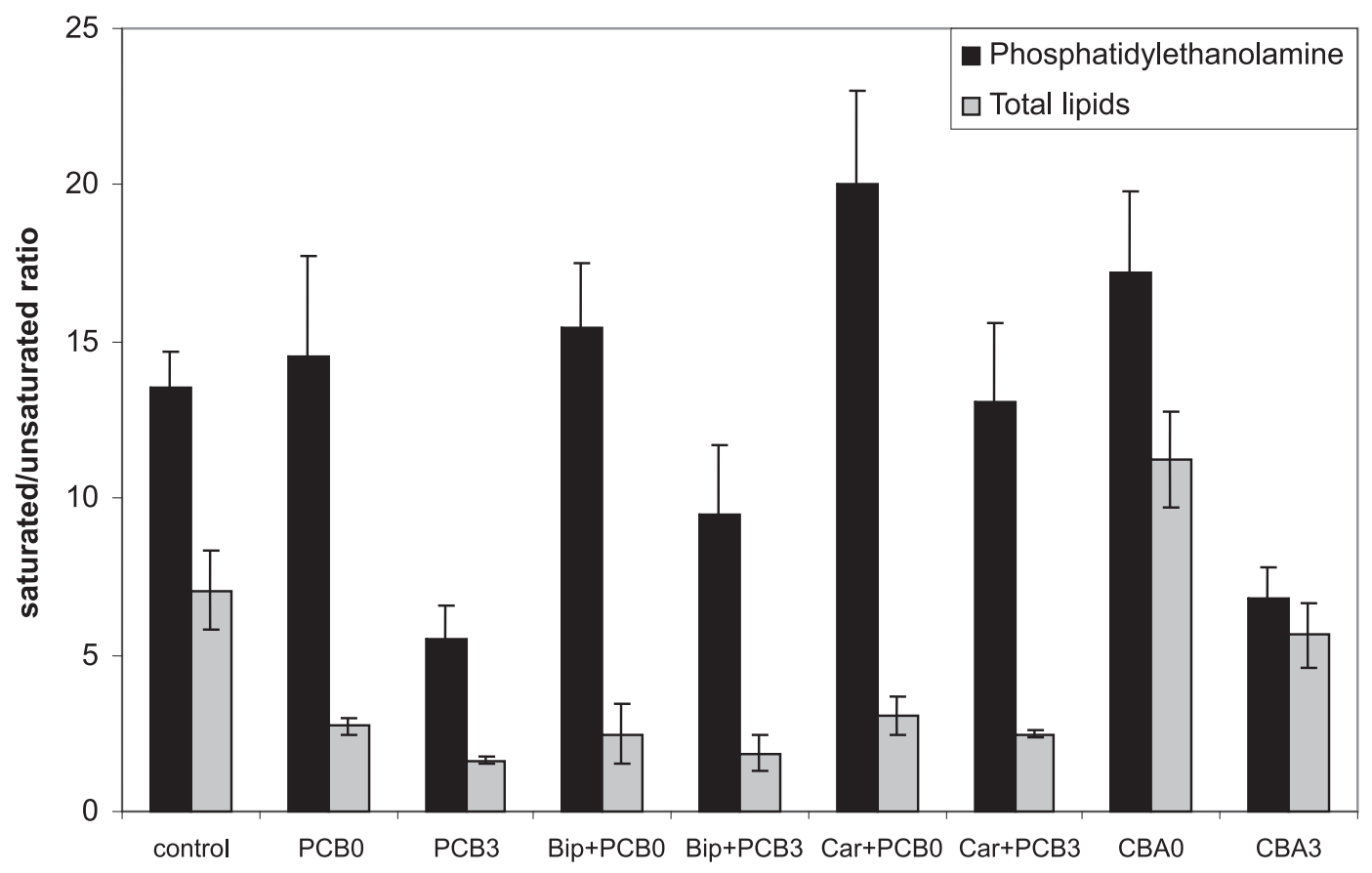

Fig. 1. Saturation/unsaturation ratio of fatty acids after six days of cultivation monitored in membrane lipids (phosphatidylethanolamine) and total lipids.

Control - experiment without PCBs or 3-CBA, PCB0, CBA0 - addition of PCBs or 3-CBA at the beginning of cultivation, PCB3, CBA3 - addition of PCBs or 3-CBA after three days of cultivation. Biphenyl (bip) and carvone (car) were added at the beginning of cultivation. 
phase. After PCB addition an increase of UFAs in total lipids (Tab. 2) was observed. This increase was followed with a rapid decrease of cyclopropyl fatty acids and slight decrease of branched acids. Increase of unsaturated fatty acids in phosphatidylethanolamine correlated with an increase in branched fatty acids and led into decrease of cyclopropyl fatty acids. Our results are in accordance with those of Heipieper et al. (2003) who reported higher cis to trans isomerisation in the presence of toxic organic compounds. The results also shows higher isomerase activity when PCBs or 3-CBA were added after three days of cultivation.

Another adaptation mechanism of bacterial cells in adverse environment is alteration of branched fatty acids. This alteration is based on an increase of iso fatty acids simultaneously with the decrease of anteiso fatty acids. This leads into more rigid membrane which protects cell core by hindering transport of toxic compound into cell (Mrozik et al. 2005). Decrease of anteiso/iso ratio increases membrane rigidity and decrease its fluidity. The addition of PCBs alone as

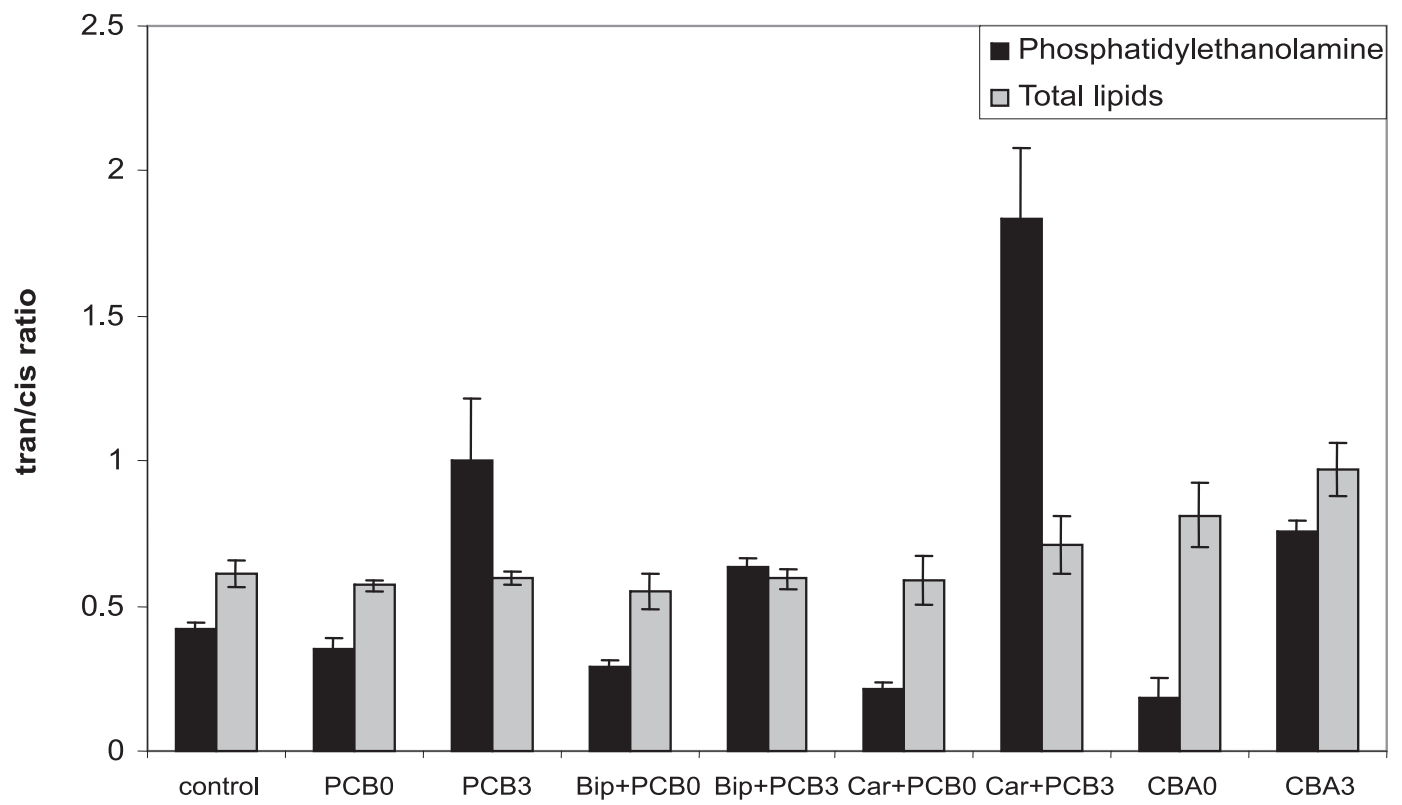

Fig. 2. Trans/cis ratio of fatty acids after six days of cultivation monitored in membrane lipids (phosphatidylethanolamine) and total lipids.

Experimental conditions according to Fig. 1.

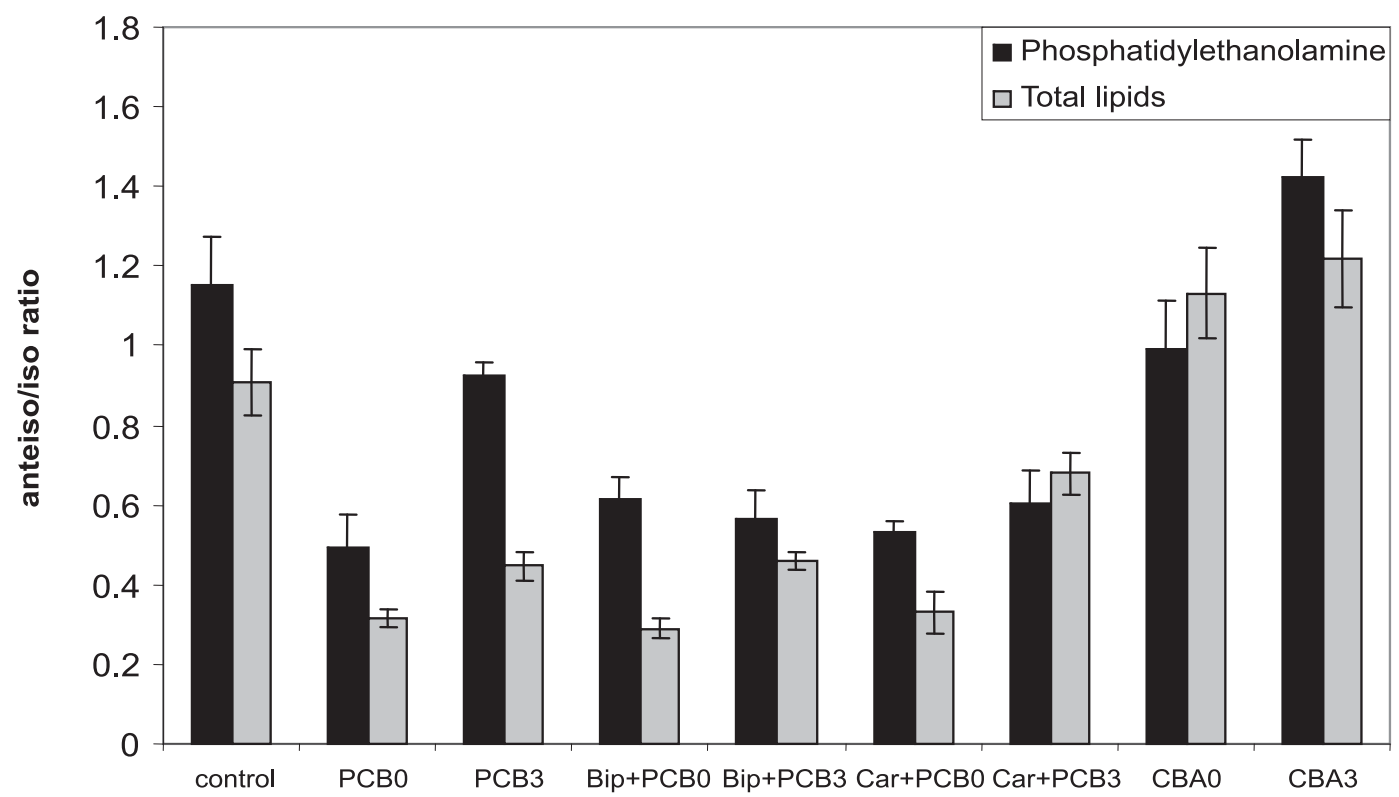

Fig. 3. Anteiso/iso ratio of fatty acids after six days of cultivation monitored in membrane lipids (phosphatidylethanolamine) and total lipids.

Experimental conditions according to Fig. 1. 
well as with biphenyl or carvone decreased membrane fluidity in all experimental sets (Fig. 3). This effect was accompanied by an increase in formation of iso branched fatty acids (Tab. 2). Lower ratio was observed in the presence of PCBs compared to control in total lipids as well. Contrary phenomenon was observed when 3-CBA was added in stationary growth phase. In our previous reports it was demonstrated that 3-CBA, a PCB metabolite inhibited PCB degradation (Vrana et al., 1996) and promote cell death (Zorádová et al. 2011). The lethal effect of 3-CBA on bacterial cells was observed only when the acid was added to media at the beginning of cultivation during lag phase. However, the addition of 3-CBA to the medium with the bacterial strain in the stationary growth phase led into growth stimulation similarly as the addition of PCBs. Briefly, the study showed better survival of bacterial strain when toxic organic compound is added in the stationary growth phase. These findings could be supported by Parnell et al. (2010) who observed increased degradation ability when cells entered the stationary growth phase. Contrarily, addition of toxic compound in lag phase lead into growth inhibition.

\section{Conclusion}

Our data showed that the survival of bacterial degraders depends on the time of contact with the particular xenobiotics. Bacterial survival is strongly dependent on this parameter. Bacterial culture in the stationary growth phase is capable to survive in adverse conditions, in the presence of toxic compounds. Summarizing, our data showed that PCBs inhibited bacterial growth, modified membrane fluidity by changing the fatty acids profile in the major membrane lipid fraction phosphatidylethanolamine and in the total lipids. Decrease in membrane fluidity as a consequence of the presence of PCBs led to the enhanced growth of biomass that might be explained by the sufficient adaptation of the bacterial strain. It is worth mentioning that 3-CBA presence led to a similar adaptation responses as the presence of PCBs.

\section{Acknowledgements}

Financial support from the Scientific Grant Agency of Ministry of Education, Science and Sport of Slovak Republic (Grant No. 1/0734/12) is gratefully acknowledged.

\section{References}

Bernal P, Segura A, Ramos, JL (2007) Microbiology 9: 1658-1664.

Čertík M, Šajbidor J (1996) Microbios 85: 151-160.
Čertík M, Shimizu S (2000) Applied Microbiology and Biotechnology 54: 224-230.

Čertík M, Breierová E (2002) Chemické listy 96: 154-159.

Čertík M, Dercová K, Sejáková Z, Find’ová M, Jakubík T (2003) Biology 58: 1111-1117.

Christopherson SW, Glass RL (1969) Journal of Dairy Science 52: 1289-1290.

Denich TJ, Beaudette LA, Lee H, Trevor SJT (2003) Journal of Microbiology and Methods 52: 149-182.

Dercová K, Vrana B, Baláž Š, Š́ndorová A (1996) Journal of Industrial Microbiology 16: 325-329.

Dercová K, Certík M, Malová A, Sejáková Z (2004) International Biodeterioration and Biodegradation 54: $251-254$

Dercová K, Čičmanová J, Lovecká P, Demnerová K, Macková M, Hucko P, Kušnír P (2008) International Biodeterioration and Biodegradation 62: 219-225.

Dercová K, Šeligová J, Dudášová H, Mikulášová M, Šilhárová K, Tóthová L, Hucko P (2009) International Biodeterioration and Biodegradation 63: 440-449.

Donnelly PK, Hedge RS, Fletcher JS (1994) Chemosphere 28: 981-988.

Duldhardt I, Gaebel J, Chrzanowski L, Nijenhuis I, Härtig C, Schauer F, Heipieper HJ (2010) Microbial Biotechnology. 3(2): 201-209.

Furukawa K, Matsumura F, Tonomura K (1978) Agricultural Biology and Chemistry 42: 543-548.

Gilbert ES, Crowley DE (1997) Applied Microbiology and Biotechnology 63: 1933-1938.

Gorbunova TI, Saloutin VI, Chupakhin ON (2010) Russian Chemical Reviews 79(6): 511-530.

Heipieper HJ, Diefenbach R, Keweloh H (1992) Applied and Environmental Microbiology 58: 1847-1852.

Heipieper HJ, Weber FJ, Sikkema J, Keweloh H, de Bont JAM (1994) TIBTECH 12: 409-415.

Heipieper HJ, Meinhardt F, Segura A (2003) FEMS Microbiology Letters 229: 1-7.

Hernandez BS, Koh S-C, Chial M, Focht DD (1997). Biodegradation 8: 153-158.

Kočan A, Petrík J, Chovancová J, Drobná B (1994) Chemosphere 29: 2315-2325.

Kočan A, Petrík J, Jursa S, Chovancová J, Drobná B (2001) Chemosphere 43: 595-600.

Martinéz P, Agulló L, Hernandéz M, SeegerM (2007) Archives of Microbiology 188: 289-297.

Maruna M, Śturdíková M, Liptaj T, Godány A, Múčková M, Čertík M, Prónayová N, Proksa B (2010) Journal of Basic Microbiology 50: 1-8.

Megharaj M, Ramakrishnan B, Venkateswarlu K, Sethunathan N, Naidu R (2011). Environment International 37: 1362-1375.

Mrozik A, Łabużek S, Piotrowska-Seget Z (2005) Microbiological Research 160: 149-157.

Mrozik A, Piotrowska-Seget Z (2010) Microbiological Research 165: 363-375.

Ohtsubo Y, Nagata Y, Kimbara K, Takagi M, Ohta A (2000) Gene 256: 223-228.

Parnell JJ, Denef VJ, Park J, Tsoi T, Tiedje JM (2010) Biodegradation 21: 147-156.

Tandlich R, Brežná B, Dercová K (2001) Chemosphere 44: $1547-1555$

Tandlich R, Vrana B, Payne S, Dercová K, Balaz S (2011) Journal of Environmental Science and Health A 46 (4): $1-8$. 
Unell M, Kabelitz N, Jansson JK, Heipieper HJ (2007) FEMS Microbiology Letters 266: 138-143.

Vrana B, Dercová K, Baláž Š (1996) Biotechnology Techniques 10: 37-40.

Vrana B, Dercová K, Baláž Š, Ševčíková A (1997) World Journal of Microbiology and Biotechnology 12: 323-326.

Šajbidor J (1997) Critical Review of Biotechnology 17: 87-103.
Zorádová S, Dudášová $H$, Lukáčová L, Dercová K, Čertík M (2011) International Biodeterioration and Biodegradation 65: 1019-1023.

Zorádová-Murínová S, Dudášová H, Lukáčová L, Čertík M, Šilharová K, Vrana B, Dercová K (2012) Applied Microbiology and Biotechnology 94: 1375-1385. 